\title{
ANALISIS FOLLOWING TO LIKES RATION TIKTOK PADA 5 BRAND KECANTIKAN TEMPAT PEMASARAN YANG LUAR BIASA
}

\author{
Alexandra Oktariani Langga
}

Alexandralangga70@gmail.com

\begin{abstract}
TikTok is a social media application launched by a Chinese company. TikTok allows users to create 15 -second videos accompanied by music, filters, and several other creative features. In Indonesia, there are 30.7 million active users, making Indonesia the country with the largest TikTok users in the world. The large number of active TikTok users in Indonesia can certainly provide an opportunity for brands to make the TikTok platform a social media marketing platform. There are 5 Beauty Brands Outstanding Marketing Places that use TikTok as a marketing platform, namely: Fenty Beauty, The Ordinary, Glow Recipe, e.l.f. Cosmetics and Too Faced. The purpose of this study is to calculate the credibility of the TikTik account performance Top 5 Beauty Brands Outstanding Marketing Places. The method used for this research is quantitative exploratory method. The results of this study indicate that the brand e.l.f. Cosmetics get the first rank and have good account performance credibility.
\end{abstract}

\begin{abstract}
ABSTRAK
TikTok merupakan aplikasi sosial media yang diluncurkan oleh perusahaan asal Tiongkok. TikTok memungkinkan penggunanya membuat video berdurasi 15 detik yang disertai dengan musik, filter, dan beberapa fitur kreatif lainnya. Di Indonesia terdapat 30,7 juta pengguna yang aktif sehingga menjadikan Indonesia sebagai negara dengan pengguna TikTok terbesar di dunia. Maraknya jumlah pengguna TikTok yang aktif di Indonesia tentu dapat memberikan peluang bagi brand untuk menjadikan platform TikTok sebagai platform social media marketing. Adapun 5 Brand Kecantikan Tempat Pemasaran Yang Luar Biasa yang memanfaat TikTok sebagai platform marketing, yaitu : Fenty Beauty, The Ordinary, Glow Recipe, e.l.f. Kosmetik dan Too Faced. Tujuan dari penelitian ini yaitu untuk menghitung kreadibilitas dari perfoma akun TikTik Top 5 Brand Kecantikan Tempat Pemasaran Yang Luar Biasa. Metode yang digunakan untuk penelitian ini yaitu metode eksploratif kuantitatif. Hasil dari penelitian ini menunjukan bahwa brand e.l.f. Kosmetik mendapatkan peringkat pertama dan memiliki kredibilitas performa akun yang baik.
\end{abstract}

Keyword : Credibility Account TikTok ; Social Media Marketing ; Social Media TikTok ; Follwing to Video Likes Ratio ; Brand Kecantikan. 


\section{PENDAHULUAN}

Teknologi seperti kebutuhan yang tidak dapat dijauhkan dari masyarakat. Manfaat teknologi informasi tidak hanya untuk meningkatkan kegiatan operasional kerja saja, tetapi juga memberikan keuntungan dan nilai tambah bagi perusahaan atau lembaga tersebut (Widodo, 2019). Manfaat teknologi di berbagai bidang kehidupan telah dirasakan banyak orang. Terutama untuk generasi milenial yang merasakan peralihan antara periode manual dengan era digital. Sebagai generasi yang melek digital, milenial terbiasa memanfaatkan smartphone dan komputer. Dengan kemajuan teknologi yang semakin pesat saat ini, bisa dikatakan teknologi informasi telah memasuki ke segala bidang, salah satunya dibidang bisnis. Bisnis tanpa adanya memanfaatkan teknologi informasi tidak akan bisa maju dan terancam bangkrut (Pamela, 2020).

Pada tahun 2020 ini di Indonesia, sosial media yang mengalami perkembangan pesat hingga menjadi budaya populer di Indonesia adalah aplikasi TikTok. Sebenarnya aplikasi TikTok bukanlah sosial media yang baru di Indonesia, karena pada beberapa tahun belakangan di tahun 2018 hingga 2019 TikTok sudah mulai dikenal di Indonesia, akan tetapi pada saat itu Tik Tok kadung menjadi aplikasi digital berbasis video yang mengeluarkan output yang sifatnya membodohkan. Bahkan, fenomena internet mengamini itu saat pengguna mengetik 'aplikasi bodoh' pada kolom alamat yang kosong. Puncaknya dari itu semua adalah saat TikTok diblokir oleh Kementerian Komunikasi dan Informatika, dengan alasan TikTok memproduksi konten negatif, terutama bagi kalangan anak-anak (https://kominfo.go.id/content/detail/13331/ini-penyebab-kominfo-putuskan-blokir-tiktok/0/sorotan_media, 2018).

Kehadiran media sosial TikTok dapat membangun sebuah brand, TikTok juga dapat membangun personal branding pemiliknya. Di Indonesia, terdapat 30,7 juta pengguna TikTok yang aktif sehingga menjadikan Indonesia sebagai negara dengan pengguna TikTok terbesar di dunia. Maraknya jumlah pengguna TikTok aktif di Indonesia tentu dapat memberikan peluang bagi brand untuk menjadikan platform ini sebagai platform social media marketing. Cukup banyak akun perushaan-perusahaan terkenal yang ada pada tiktok, contohnya seperti Brand Kecantikam Tempat Pemasaran yang Luar Biasa. Adapun 5 Brand Kecantikam Tempat Pemasaran yang Luar Biasa, diantaranya yaitu : Fenty Beauty, The Ordinary, Glow Recipe, e.l.f. Kosmetik dan Too Faced (Gorby Zumroni, 2021a).

Penelitian ini menggunakan metode eksploratif kuantitatif, dan akan menghitung menggunakan rasio-rasio yang ada pada TikTok. Pada penelitian (I Putu Hendika Permana \& Ni Putu Suci Meinarni, 2021)menjelaskan bahwa terdapat 17 rasio yang ada pada sosial media TikTok dan relevan digunakan sebagai media ukur kredibilitas akun yang ada. Penelitian ini hanya berfokus untuk menghitung kredibilitas Following to Video Likes Ratio pada 5 Brand Kecantikam Tempat Pemasaran yang Luar Biasa Tujuan dari penelitian ini adalah mengetahui kredibilitas performa dari akun TikTok 5 Brand Kecantikam Tempat Pemasaran yang Luar Biasa menggunakan Following to Video Likes Ratio (Gorby Zumroni, 2021b). 


\section{TINJAUAN PUSTAKA}

Perkembangan bidang teknologi saat ini terjadi begitu pesat. Melalui perkembangan yang terjadi dari waktu ke waktu menimbulkan maraknya aplikasi-aplikasi serta platform mediasosial yang bermunculan. Aplikasi yang sangat diminati oleh masyarakat saat ini diantaranyaadalah TikTok, Instagram, Twitter, WhatsApp dan yang lain sebagainya. Seiring berjalannyawaktu, aplikasi sosial media tersebut dapat menjadi candu bagi kalangan masyarakat. Tidak hanya kalangan remaja yang menggunakan aplikasi sosial media, orang tua bahkan anak-anak juga aktif menggunakan aplikasi sosial media tersebut.

Media sosial menghubungkan orang didunia untuk saling berhubungan satu sama lain. Seiring perkembangan teknologi yang berkembang pesat dengan munculnya internet memunculkan berbagai aplikasi di media sosial yang memberikan peluang sebuah usaha. Saat ini sudah banyak usaha yang menggunakan media sosial untuk mempromosikan produk dan menjadikannya sebagai strategi bisnis.

Tik Tok adalah aplikasi yang memberikan special effects unik dan menarik yang dapat digunakan oleh penggunanya dengan mudah sehingga dapat membuat video pendek dengan hasil yang keren serta dapat dipamerkan kepada teman-teman atau pengguna lainnya. Dan juga TikTok adalah platform media sosial yang fokus pada sharing konten video. Setiap video berdurasi 15 detik dan dapat digabung menjadi 60 detik. Platform ini bisa jadi sarana buat promosi produk bisnis.(Putri Aprilia, 2021).

Saat ini cukup banyak platform yang mendukung strategi digital marketing ini, diantaranya adalah TikTok. Aplikasi dengan 800 juta pengguna aktif ini menjadi salah satu sumber video dan meme viral terbesar di internet. TikTok juga telah diunduh oleh sekitar 1.5 miliar pengguna di Google Playstore dan Apps Store sehingga dapat dimanfaatkan oleh brand untuk melakukan strategi marketing. Selain itu Tik Tok juga meraih Peringkat 1 dalam AppsFlyer Growth Index 2020 sebanyak 2 kali berturut-turut Tingginya minat dan cepatnya persebaran konten dari TikTok ke seluruh platform media sosial ini menjadi daya tarik tersendiri dalam dunia marketing online dari sini kita dapat berasumsi bahwa TikTok memiliki potensi besar to be the next instagram, dan tentu saja, alat selanjutnya untuk menyebarkan kesadaran merek suatu produk. Jika Anda menggunakan TikTok dengan benar, Anda dapat memperkenalkan bisnis atau produk Anda kepada khalayak luas.(Eva Novianti Hestivera, 2020).

Aplikasi TikTok tidak hanya digunakan untuk membuat konten video dengan tujuan menghibur pengguna lainnya. Aplikasi TikTok juga dapat dijadikan peluang bagi brand atau perusahaan sebagai platform social media marketing. Penelitian (Nurjihan Pricillia Purnamasari, 2021) menyatakan bahwa TikTok berpengaruh positif dan signifikan terhadap minat beli atau berbelanja secara online. Sehingga dengan ini, TikTok mampu memberikan peluang yang sangat tinggi bagi perusahaan-perusahaan dalam melakukan digital marketing.

TikTok dirasakan memiliki kekuatan ataupun pengaruh dalam industri, sehingga menimbulkan kualitas akun yang menentukan strata maupun kredibilitas pemilik akun. Kredibilitas akun TikTok merupakan suatu hal yang cukup penting untuk berbagai 
kepentingan. Kredibilitas sebuah akun TikTok dapat diukur dari tingkat performa yang dihasilkan secara matematis. Dalam mengukur performa diperlukan skala pengukuran yang tertuang ke dalam rasio.

\section{MOTEDE PENELITIAN}

Penelitian ini menggunakan metode eksploratif kuantitatif untuk mengetahui kredibilitas dari performa akun TikTok 5 brand Kecantikan Tempat Pemasaran yang luar biasa. Penelitian eksplorasi adalah riset yang digunakan untuk menyelidiki masalah yang tidak didefinisikan dengan jelas. Hal ini dilakukan untuk memiliki pemahaman yang lebih baik tentang masalah yang ada, tetapi tidak akan memberikan hasil yang konklusif. Oleh karena itulah arti penelitian ini merujuk pada sikap seorang peneliti memulai dengan ide umum dan menggunakannya sebagai media untuk mengidentifikasi masalah sehingga dapat menjadi fokus untuk penelitian di masa mendatang. Aspek penting di sini adalah bahwa peneliti harus bersedia mengubah arahnya dengan pengungkapan data atau wawasan baru (Hayati, 2021).

Tujuan dari penelitian ini yaitu mengetahui nilai kredibillitas dari performa akun TikTok 5 Brand Kecantikan Tempat Pemasaran Yang Luar Biasa. Ada beberapa langkah yang harus dilakukan dalam penelitian ini, sehingga mampu menemukan peringkat pertama akun TikTok Brand Kecantikan Tempat Pemasaran yang Luar Biasa yang memiliki performa terbaik. Langkah-langkah yang dilakukan pada penelitian ini, diantaranya yaitu :

\section{Melakukan Eksplorasi Pada Website Untuk Menentukan Objek yang Akan Dianalisa.}

Eksplorasi ini dilakukan pada beberapa halaman website yang menyediakan informasi mengenai objek yang akan di teliti. Setelah ekslorasi selesai dilakukan, sehingga ditemukan nama-nama Brand Kecantikan Yang Luar Biasa yang akan dijadikan objek analisa. Setelah melakukan eksplorasi pada halaman website, maka langkah selanjutnya yaitu mencari nama akun TikTok dari masing-masing Brand Kecantikan. Pastikan semua Brand memiliki akun pada aplikasi sosial media TikTok.

\section{Menghitung Nilai Rata-Rata Variable Dari 5 Brand Kecantikan Yang Luar Biasa.}

Pada langkah ini, peneliti menghitung nilai variable Following dan variable video LIkes. Variabel adalah besaran yang dapat berubah serta berpengaruh pada sebuah peristiwa atau hasil dari penelitian. Keberadaan variabel sendiri nantinya bisa mempermudah Anda untuk menganalisis atau mengidentifikasi permasalahan yang ada (Saddoen, n.d.). Untuk menghitung nilai rata-rata dari variable Following dan variabel video Likes yaitu dengan cara mengambil minimal 10 postingan kemudian di hitung sehingga menemukan nilai rata-rata dari masing-masing variabel. 


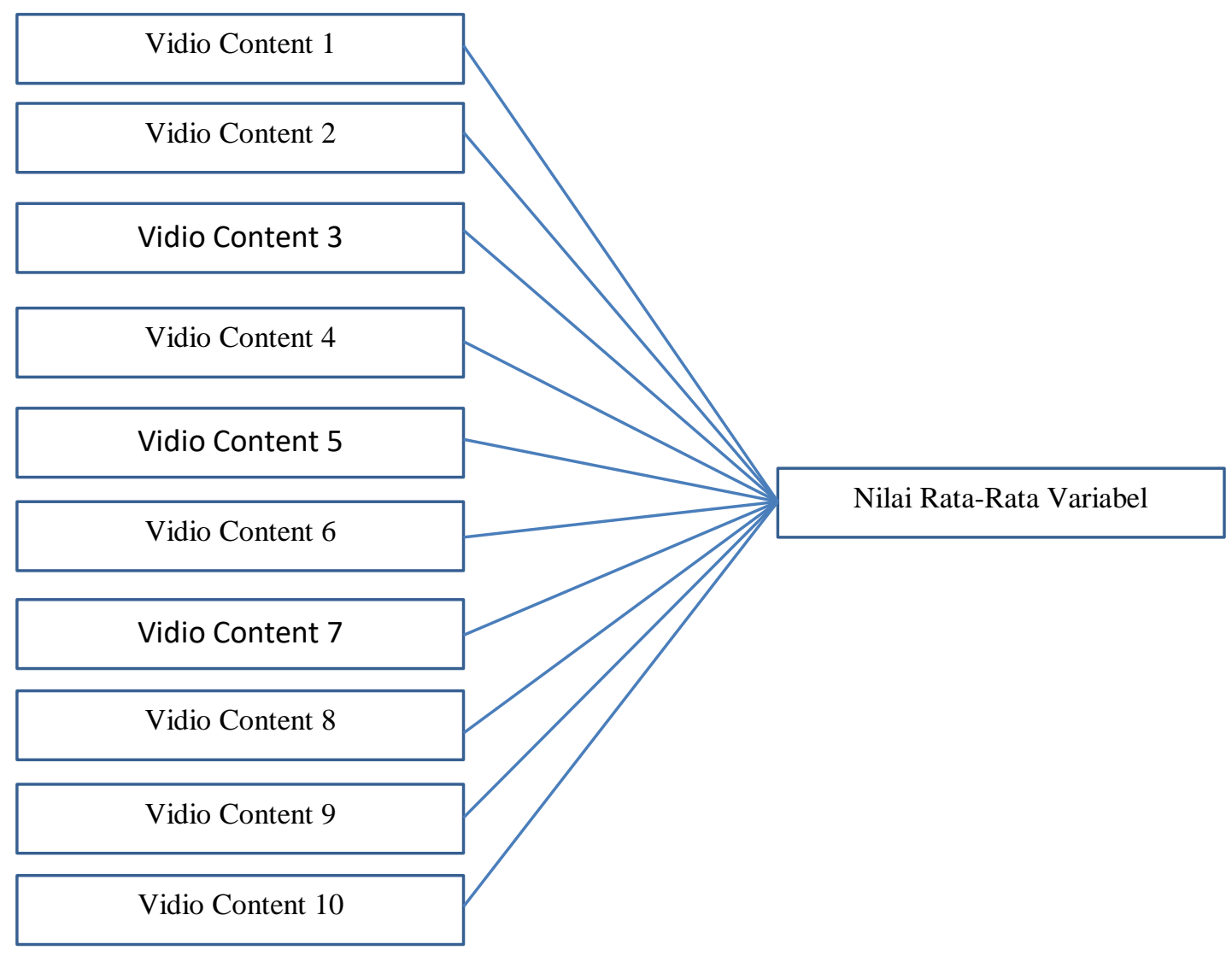

\section{Menghitung Nilai Kredibilitas Rasio}

Untuk menghitung nilai kredibilitas dari Following to video LIkes, peneliti menggunakan cara membagi nilai variabel pertama dengan nilai variabel kedua. Jika Following memiliki nilai 182 dan video Likes memiliki nilai 134.122, maka cara menghitungnya yaitu $182: 134.122=67.147$. Dengan begitu nilai dari Following to video Likes ratio adalah 67.147.

\section{Menentukan Peringkat Pada Akun TikTok}

Pada langkah terakhir yang dilakukan pada penelitian ini yaitu menentukan peringkat pada masing-masing rasio yang ada. Pada penentuan peringkat perlu melihat karakteristik dari rasio yang di teliti. Jika karakteristik rasio merupakan rendah, maka objek yang memiliki nilai terendah akan mendapatkan angka 5 dan objek yang memiliki nilai tertinggi akan mendapatkan angka 1. Namun jika rasio memiliki karakteritik tinggi maka objek yang mendapatkan nilai tinggi akan mendapatkan angka 5 dan objek yang mendapatkan nilai terendah akan mendapatkan angka 1. Setelah mendapatkan hasil kredibilitas ratio maka dapat disimpulkan objek yang mana mendapatkan peringkat 1 sampai dengan peringkat 5 . 


\section{HASIL DAN PEMBAHASAN}

Akun TikTok dari Top 5 Brand Kecantikan Tempat Pemasaran Yang Luar Biasa, diantaranya

1. Fenty Beauty

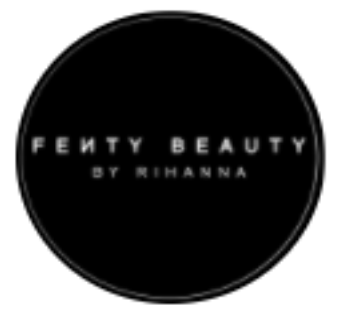

\section{fentybeauty}

Fenty Beauty

\section{Follow}

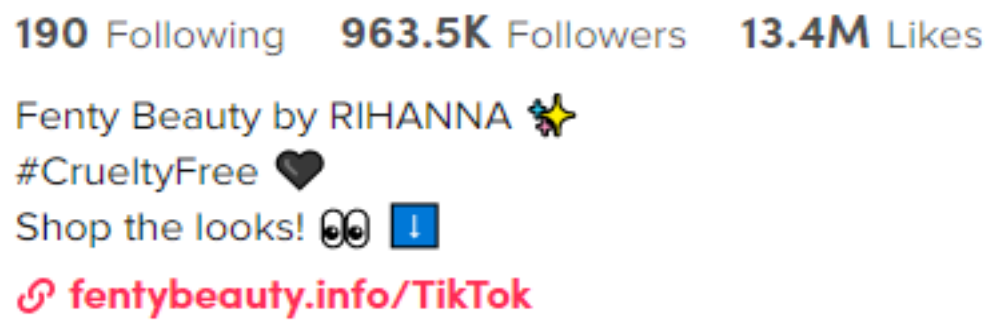

\section{The Ordinary}

\section{theordinary}

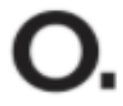

The Ordinary

\section{Follow}

The Ordinary. Clinical formulations with integrity.

A DECIEM Brand

$\mathcal{O}$ theordinary.deciem.com

Gambar 2. Akun Tiktok The Ordinary

Sumber : https://www.tiktok.com/@theordinary? (Akses 20-10-2021) 


\section{Glow Recipe}

\section{glowrecipe \\ GLOW Glow Recipe RECIPE \\ Follow \\ 156 Following 201K Followers 1.9M Likes \\ Fruit-forward. Clinically effective. Glowing skin. क. 0 G \\ $\mathcal{O}$ linkin.bio/glowrecipe/tiktok}

Gambar 3. Akun Tiktok Glow Recipe

Sumber : https://www.tiktok.com/@glowrecipe? (Akses 20-10-2021)

\section{4. e.l.f. Kosmetik}

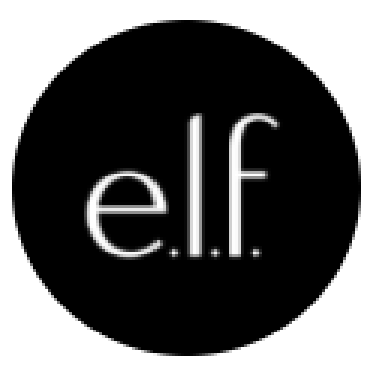

\section{elfyeah} elfyeah

\section{Follow}

54 Following 348.5K Followers 9M Likes

it it's the e.l.fing amazing content for us th 100\% vegan + cruelty-free $\mathbf{B}$ (:)

$\mathcal{O}$ www.elfcosmetics.com

Gambar 4. AKun Tiktok e.l.f. Kosmetik

Sumber : https://www.tiktok.com/@elfyeah? (Akses 20-10-2021) 


\section{Too Faced}

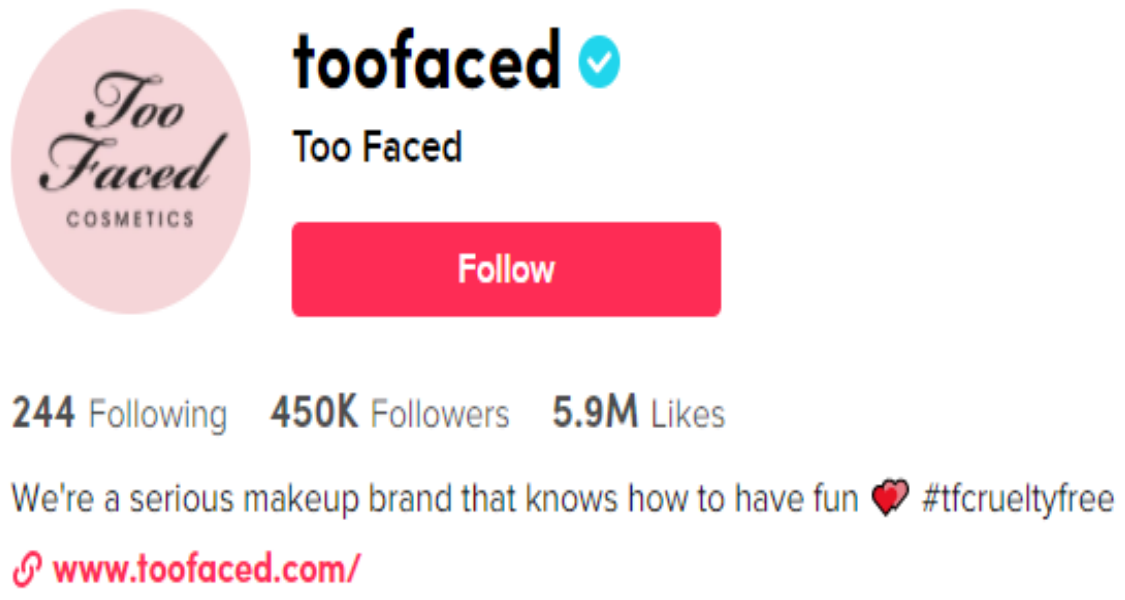

Gambar 5. Akun Tiktok Too Faced

Sumber : https://www.tiktok.com/@toofaced? (Akses 20-10-2021)

Dari kelima akun TikTok Top 5 Brand Kecantikan Tempat Pemasaran Yang Luar Biasa, peneliti menemukan nilai dari masing-masing variabel yang ada untuk menghitung rasio Following to Video Likes dari setiap akun. Pada akun TikTok terdapat 7 variabel, diantaranya yaitu :

1) Likes

2) Followers

3) Following

4) Video Likes

5) Video Comments

6) Video Share

7) Video Views

Dari ketujuh variabel tersebut peneliti hanya fokus untuk menemukan hasil dari 2 variabel, yaitu :

1) Following

2) Video Likes

Dari kedua variabel tersebut kemudian dianalisa sehingga menemukan nilai rata-rata dari variabel Following dan variabel video Likes. Untuk menghitung nilai rata-rata dari variabel Following dan variabel video Likes yaitu dengan cara mengambil minimal 10 postingan kemudian di hitung sehingga menemukan nilai rata-rata dari masing-masing variabel. Berikut merupakan tabel nilai rata-rata dari masing-masing Brand Kecantikan, yaitu : 
Tabel 1. Analisa Nilai Rata-Rata Nilai Variabel Following dan Video Likes Akun TikTok Fenty Beauty

\begin{tabular}{|l|l|l|}
\hline No & Vedio Following & Likes \\
\hline 1 & 182 & 8.139 \\
\hline 2 & 182 & 724.000 \\
\hline 3 & 182 & 1.955 \\
\hline 4 & 182 & 5.008 \\
\hline 5 & 182 & 1.415 \\
\hline 6 & 182 & 474.000 \\
\hline 7 & 182 & 109.000 \\
\hline 8 & 182 & 933 \\
\hline 9 & 182 & 9.817 \\
\hline 10 & 182 & 6.848 \\
\hline Total & $\mathbf{1 8 2}$ & $\mathbf{1 3 4 . 1 1 2}$ \\
\hline \multicolumn{2}{|l|}{ Sumber : Pengolah Data Exel } \\
\hline
\end{tabular}

Tabel 2. Analisa Nilai Rata-Rata Nilai Variabel Following dan Video Likes Akun TikTok The Ordinary

\begin{tabular}{|l|l|l|}
\hline No & Vedio Following & Likes \\
\hline 1 & 1 & 2.601 \\
\hline 2 & 1 & 970 \\
\hline 3 & 1 & 1.406 \\
\hline 4 & 1 & 411 \\
\hline 5 & 1 & 1.581 \\
\hline 6 & 1 & 443 \\
\hline 7 & 1 & 323 \\
\hline 8 & 1 & 3.314 \\
\hline 9 & 1 & 1.027 \\
\hline 10 & 1 & 7.182 \\
\hline Total & $\mathbf{1}$ & $\mathbf{1 . 9 2 6}$ \\
\hline
\end{tabular}


Tabel 3. Analisa Nilai Rata-Rata Nilai Variabel Following dan Video Likes Akun TikTok Glow Recipe

\begin{tabular}{|l|l|l|}
\hline No & Vedio Following & Likes \\
\hline 1 & 156 & 8.574 \\
\hline 2 & 156 & 126 \\
\hline 3 & 156 & 165 \\
\hline 4 & 156 & 568 \\
\hline 5 & 156 & 533 \\
\hline 6 & 156 & 763 \\
\hline 7 & 156 & 462 \\
\hline 8 & 156 & 867 \\
\hline 9 & 156 & 567 \\
\hline 10 & 156 & 908 \\
\hline Total & $\mathbf{1 5 6}$ & $\mathbf{1 . 3 5 3}$ \\
\hline
\end{tabular}

Tabel 4. Analisa Nilai Rata-Rata Nilai Variabel Following dan Video Likes Akun TikTok e.l.f. Kosmetik

\begin{tabular}{|c|c|c|}
\hline No & Vedio Following & Likes \\
\hline 1 & 51 & 1.948 .000 \\
\hline 2 & 51 & 2.252 .000 \\
\hline 3 & 51 & 60.000 \\
\hline 4 & 51 & 282 \\
\hline 5 & 51 & 2.121 \\
\hline 6 & 51 & 899 \\
\hline 7 & 51 & 318 \\
\hline 8 & 51 & 2.062 \\
\hline 9 & 51 & 1.922 \\
\hline 10 & 51 & 342 \\
\hline Total & 51 & 426.795 \\
\hline
\end{tabular}


Tabel 5. Analisa Nilai Rata-Rata Nilai Variabel Following dan Video Likes Akun TikTok Too Faced

\begin{tabular}{|l|l|l|}
\hline No & Vedio Following & Likes \\
\hline 1 & 243 & 357 \\
\hline 2 & 243 & 108.000 \\
\hline 3 & 243 & 8.263 \\
\hline 4 & 243 & 38 \\
\hline 5 & 243 & 137 \\
\hline 6 & 243 & 130 \\
\hline 7 & 243 & 98 \\
\hline 8 & 243 & 196 \\
\hline 9 & 243 & 183 \\
\hline 10 & 243 & 315 \\
\hline Total & $\mathbf{2 4 3}$ & $\mathbf{1 1 7 7 1 , 7}$ \\
\hline
\end{tabular}

Setelah menghitung nilai rata-rata tersebut, maka akan menemukan hasil akhir nilai rata-rata dari variabel Following dan video Likes

Tabel 6. Nilai Variabel Pada Akun TikTok Top 5 Brand Kecantikan Tempat Pemasaran Yang Luar Biasa

\begin{tabular}{|l|l|l|l|l|l|}
\hline Variable & \multicolumn{1}{|c|}{$\begin{array}{c}\text { Fenty } \\
\text { Beauty }\end{array}$} & $\begin{array}{c}\text { The } \\
\text { Ordinary }\end{array}$ & $\begin{array}{l}\text { Glow } \\
\text { Recipe }\end{array}$ & e.l.f. Kosmetik & Too Faced \\
\hline Likes & 134.112 & 1.926 & 1.353 & 426.795 & 11771.7 \\
\hline Following & 182 & 1 & 156 & 51 & 243 \\
\hline \multicolumn{7}{|c|}{ Sumber : Pengolah Data Excel }
\end{tabular}

Pada akun TikTok terdapat 17 rasio yang relevan digunakan untuk mengukur kredibilitas pada masing-masing akun. Namun pada penelitian kali ini hanya berfokus untuk menghitung Following to Video Likes Ratio. Untuk menghitung kredibilitas dari masing-masing akun TikTok setiap Brand Kecantikan, peneliti menghitung dengan cara : variabel 1 akan dibagi dengan variabel 2, sehingga ditemukan hasil analisisa dari rasio tersebut.

Tabel 7. Hasil Perhitungan Rasio Akun TikTok

\begin{tabular}{|l|l|l|l|l|l|l|}
\hline No & RATIO & $\begin{array}{l}\text { Fenty } \\
\text { Beauty }\end{array}$ & $\begin{array}{l}\text { The } \\
\text { Ordinary }\end{array}$ & $\begin{array}{l}\text { Glow } \\
\text { Recipe }\end{array}$ & $\begin{array}{l}\text { e.l.f. } \\
\text { Kosmetik }\end{array}$ & $\begin{array}{l}\text { Too } \\
\text { Faced }\end{array}$ \\
\hline 1 & $\begin{array}{l}\text { Following to } \\
\text { Likes Ratio }\end{array}$ & 67.147 & 964 & 755 & 213.423 & 243 \\
\hline
\end{tabular}

Sumber : Pengolah Data Excel

Following to Video Likes Ratio memiliki karakteristik yang tinggi, artinya semakin tinggi nilai yang dihasilkan maka semakin baik kredibilitas dari performa akun tersebut. Untuk memberikan peringkat pada masing-masing Brand Kecantikan ini, peneliti memberikan 
angka 5 kepada Brand Kecantikan yang mendapatkan nilai tertinggi dan angka 1 untuk Brand Kecantikan yang mendapatkan nilai terendah. Berikut merupakan tabel urutan nilai yang dihasilkan oleh masing-masing vendor Brand Kecantikan

Tabel 8. Nilai Rasio Akun TikTok Top 5 Brand Kecantikan Tempat Pemasaran Yang Luar Biasa

\begin{tabular}{|l|l|l|l|l|l|l|}
\hline No & RATIO & $\begin{array}{c}\text { Fenty } \\
\text { Beauty }\end{array}$ & $\begin{array}{c}\text { The } \\
\text { Ordinary }\end{array}$ & $\begin{array}{c}\text { Glow } \\
\text { Recipe }\end{array}$ & $\begin{array}{c}\text { e.l.f. } \\
\text { Kosmetik }\end{array}$ & $\begin{array}{c}\text { Too } \\
\text { Faced }\end{array}$ \\
\hline 1 & $\begin{array}{l}\text { Following to } \\
\text { Likes Ratio }\end{array}$ & 4 & 3 & 2 & 5 & 1 \\
\hline
\end{tabular}

. Sumber : Pengolah Data Excel

Dari Tabel Nilai Rasio Akun TikTok Top 5 Brand Kecantikan Tempat Pemasaran Yang Luar Biasa dapat simpulkan bahwa e.l.f. Kosmetik mendapatkan nilai tertinggi untuk rasio Following to Video Likes. Sedangkan akun TikTok Too Faced mendapatkan nilai terendah untuk rasio ini. Jadi, pada penelitian ini e.l.f Kosmetik memiliki kredibilitas performa yang lebih baik dibandingkan dengan Brand Kosmetik yang lainnya.

\section{KESIMPULAN}

Tujuan dari penelitian ini adalah mengetahui kreadibilitas perfoma dari akun TikTok Top 5 Brand Kecantikan Tempat Pemasaran Yang Luar Biasa menggunakan Following to Video Likes Ration. Top 5 Brand Kecantikan Tempat Pemasaran Yang Luar Biasa tersebut diantaranya : Fenty Beauty, The Ordinary, Glow Recipe, e.l.f. Kosmetik dan Too Faced. Dari kellima Brand Kecantikan Tempat Pemasaran Yang Luar Biasa tersebut dapat disimpulkan bahwa :

1. Peringkat pertama diraih oleh vendor e.l.f. Kosmetik dengan nilai tertinggi yaitu 213.423

2. Peringkat kedua diraih oleh vendor Fenty Beauty dengan nilai 67.147

3. Peringkat ketiga diraih oleh vendor The Ordinary dengan nilai 964

4. Peringkat keempat diraih oleh vendor Glow Recipe dengan nilai 755

5. Peringkat kelima diraih oleh vendor Too Faced dengan nilai terendah yaitu 243 


\section{DAFTAR PUSTAKA}

Eva Novianti Hestivera. (2020). Memanfaatkan TikTok Sebagai Digital Marketing Dalam Bisnis Online. ThetanjungpuraTimes.Com. https://thetanjungpuratimes.com/2020/08/03/memanfaatkan-tiktok-sebagai-digital marketing-dalam-bisnis-online/

Gorby Zumroni. (2021a). 5 Brand Kecantikan yang Menggunakan TikTok Sebagai Tempat Pemasaran yang luar Biasa. SRAGEN UPDATE. https://sragenupdate.pikiranrakyat.com/gaya-hidup/pr-1842392279/5-brand-kecantikan-yang-menggunakan-tiktoksebagai-tempat-pemasaran-yang-luar biasa?_gl=1\%2A16v494q\%2A_ga\%2AcV9wVXVsVVNkUlpwZDBLQWRRX3pEOU 9nd1VfUkdLLXZhVVBWLV91bURLNUUxQTkzaHY3QkJUeEZ4Mlc2eE

Gorby Zumroni. (2021b). 5 Brand Kecantikan yang Menggunakan TikTok Sebagai Tempat Pemasaran yang luar Biasa. SRAGEN UPDATE. https://sragenupdate.pikiranrakyat.com/gaya-hidup/pr-1842392279/5-brand-kecantikan-yang-menggunakan-tiktoksebagai-tempat-pemasaran-yang-luarbiasa?_gl=1\%2A16v494q\%2A_ga\%2AcV9wVXVsVVNkUlpwZDBLQWRRX3pEOU 9nd1VfUkdLLXZhVVBWLV91bURLNUUxQTkzaHY3QkJUeEZ4Mlc2eE5keg

Hayati, R. (2021). Pengertian Penelitian Eksplorasi, Macam, Ciri, dan Cara Menulisnya. PenelitianIlmiah.Com. https://penelitianilmiah.com/penelitian-eksplorasi/

https://kominfo.go.id/content/detail/13331/ini-penyebab-kominfo-putuskan-blokir-tiktok/0/sorotan_media. (2018). Ini Penyebab Kominfo Putuskan Blokir Tik Tok. Www.Viva.Co.Id. https://kominfo.go.id/content/detail/13331/ini-penyebab-kominfoputuskan-blokir-tik-tok/0/sorotan_media

I Putu Hendika Permana, \& Ni Putu Suci Meinarni. (2021). Ratio Analysis on Tiktok (Social Media) for Qualitative Research Using Explorative Methods. Jurnal Ekonomi \& Bisnis JAGADITHA, 8(1), 30-38. https://doi.org/10.22225/jj.8.1.2944.30-38

Nurjihan Pricillia Purnamasari, R. P. T. (2021). Analisis Resepsi Remaja Perempuan terhadap Gaya Hidup Berbelanja Fashion Melalui Tayangan Video 'Belanja Gak Aturan' dalam Akun Tiktok. Jurnal Studi Komunikasi Dan Media. http://jurnal.untagsby.ac.id/index.php/representamen/article/view/5129

Pamela. (2020). Manfaat Teknologi di Bidang Bisnis dan Investasi. Ajaib.Co.Id. https://ajaib.co.id/manfaat-teknologi-di-bidang-bisnis-dan-investasi/

Putri Aprilia. (2021). 9 Tips Meningkatkan Penjualan Bisnis Online dengan TikTok. Niagahoster Blog. https://www.niagahoster.co.id/blog/strategi-marketing-tiktok/

Saddoen, A. (n.d.). Pengertian Variabel : Definisi, Jenis-Jenis, Manfaat dan Contohnya. Pengertian Variabel. Retrieved November 11, 2021, from https://moondoggiesmusic.com/pengertian-variabel/\#gsc.tab=0 
Widodo, A. S. (2019). Peran Internet dalam Meningkatkan Jumlah Pekerja Lepas di Indonesia. Nyimak: Journal of Communication.

https://doi.org/10.31000/nyimak.v3i2.1811 